\title{
The Great Debate *
}

\author{
by Irving S. Friedman **
}

I am pleased to have the opportunity to address this distinguished audience. It is an audience that needs not to be persuaded of the importance of inflation for modern economies. Whether seen in its broadest aspect on a global scale or in its smallest aspect, such as the individual and the firm, people in your profession are deeply involved in handling the many problems created by our persistent global inflation.

Wherever I go in different countries throughout the world, I find that people are talking about inflation. Wherever I go they ask about the policies of the U.S. Administration. Often the questions deal with some specifics, such as interest rates, or the meaning of words like supply side economics, or the outlook for the U.S. balance of payments and the position of the dollar.

A Great Debate has now begun in the United States on our social and economic system, priorities and institutions. It may be that this Debate will come to naught. It is more likely, however, that out of this Great Debate will emerge a markedly changed America with changes of deep and lasting major influences on the rest of the world.

The Debate centers on fiscal, monetary and credit policies. For Americans these policy issues are not technical subjects discussed by relatively few. They are truly popular subjects discussed by the majority of citizens. Money and credit have been major instruments of economic and social mobility throughout American history. It is true today. Money and credit remain at the center of American politics and ideological differences.

Monetary and economic problems have thus long been the subject matter of American politics. They have always been politically controversial and have deeply stirred American emotions. The Founding Fathers like Jefferson and Hamilton expressed themselves vigorously and thoughtfully, often in disagreement with each other, on monetary and credit matters. In the subsequent decades and centuries, bimetallism, paper money, Gold Standard, central banking and the public debt have been issues in nearly every U.S. Administration. The intellectual and even emotional responses by Americans to monetary and credit policies and to anti-inflationary programs derive from lessons they have learned in the past.

* Address Given at the General Assembly of Members, The Geneva Association, at London, England, on Wednesday, July 8, 1981.

** Senior International Advisor, The First Boston Corporation. 
As individuals they do not attach the same weight to each of these lessons. By and large, they divide into conservatives and populists. The conservatives have always stressed sound money ; money which commands the confidence of people in all its attributes and which does not decline in purchasing power. Populists have stressed money as a means of creating or giving what is regarded as adequate purchasing power to people to spend or invest, even if this results in money losing its purchasing power and eroding public confidence in money in nearly all of its attributes except being legal tender.

It would be in line with American experience and tradition to explore fully the issues raised by President Reagan's program and to find a new consensus which would become the framework for American social and economic policies for the remainder of this century. Not since the days of the New Deal in the 1930s, have economic and social questions of this profound importance occupied the attention of the American people. The consensus of the 1930 s provided the framework for economic and social policies for nearly fifty years. This consensus is now being challenged and is likely to be changed.

The inflation we are experiencing today in the United States, and the policy responses have their deep roots in this American experience.

In the Great Depression the American people thought they learned that rising prices could be an effective stimulant to a badly depressed economy. Rising prices were considered signs of recovery. The American people thought they learned that a devaluation of the dollar in terms of gold could help stimulate the economy. The American people also thought they learned that by ending adherence to the Gold Standard they could obtain the freedom to pursue expansive monetary policies which would help lead to the much desired prosperity. During the Depression the American people became convinced, more than ever before, that monetary and fiscal policies were the handmaidens of politics. The day-to-day management of money was technical, but the purposes and instruments were greatly influenced by broader political ideology and philosophy.

In the years after World War II, as we all know, the emphasis in American policy was primarily on achieving and maintaining high levels of employment and avoiding unemployment, maintaining satisfactory rates of growth, and the distribution of the benefits of this growth among the widest possible sectors of people. In addition, more and more attention was paid to social conditions such as the welfare of the aged, ill, less privileged minorities, students, children, etc. With these social objectives now becoming part of the responsibilities of government, the political process became more deeply imbedded than ever in the economic life of the nation. High taxes, widespread subsidies, increasing government expenditures, expansion of the use of credit by the private and governement sectors, became commonplace. For the politically conservative some comfort was found in the "Accord" of March, 1951, between the Federal Reserve and the U.S. Treasury. This Accord ended the support of government bonds and notes by the Federal Reserve at fixed rates of interest. This support policy was used during World War II and made monetary policy nearly meaningless. After the Accord, monetary policy could again be used with greater flexibility and effectiveness. To help those who were worried about maintaining full employment, the Federal Reserve concentrated for many years on the short end of the money market through its 
so-called " bills only" policies. Let short-term rates rise to defend currency values, but try to keep long-term rates from rising to help promote investment, output and employment. Populist politics dominated economic and social policy-making.

Among the political and economic conservatives were many who believed that managed-paper money, even within the constraints of a U.S. dollar tied to gold internationally, was unsatisfactory. They feared that governments would not be able to resist the temptation to increase expenditures to high levels which would require printing press-financing or would consume the private savings needed for productive investment. The Gold Standard was for them the needed constraint to bring about price stability and a more efficient, innovative economy. Such advocates could not overcome the burden of history. Failures and miseries of the Great Depression were largely attributed to the Gold Standard. The Depression was seen as the prelude to the horrors of World War II.

We do not know what might have happened if the United States had returned to the Gold Standard. In any case, it was never a politically feasible alternative to the monetary policies that were actually adopted and followed. What we do know is that we have had inflation in the U.S. since World War II. We have passed for some years from a public acquiescence in this inflation to a public distaste and concern. Indeed, in a very recent poll conducted by the magazine Newsweek, $60 \%$ of those polled said that they would oppose increased defense spending if inflation would remain at the current level or go higher. In the same poll the majority of those polled were prepared to favor increased defense spending even though it resulted in higher taxes than otherwise.

Americans of all political views fear that inflation will continue to be a major factor in their lives for the foreseeable years ahead. Many even believe that the political process will not provide a solution which is sufficiently acceptable to the American people to bring to an end the inflation and expectations of its continuation.

A very brief review of the history of U.S. inflation may be useful before commenting on the current situation. The long-term history of U.S. price behavior is summarized in the following Chart I. (next page). I will concentrate on the more recent years.

The cost of living index in the United States increased by an average of 1.7 percent per year during the $1954-1968$ period. These years were the post-Korean War phase until the expanded phase of the Viet Nam War. This was much less than the 3.5 percent average increase registered for world consumer prices. At the time, I was deeply concerned with U.S. inflation because consumer prices should have been falling markedly during those years, instead of rising. Thus, from an economic viewpoint, I was concerned that the true rate of inflation in the United States was more like 5 percent or more. It tried to understand why our price behavior was not following historical paths, and I favored increased taxes during the Viet Nam War. I regard 1968 as the year when the United States entered the new era of expectations of persistent inflation, and past experience no longer was a guide to forecasting or policy-making.

In the years between 1968 and 1973, before the oil price increases, inflation not only accelerated, but reached levels which frightened the American public and government though it still averaged below 5 percent per annum and was still well below the 


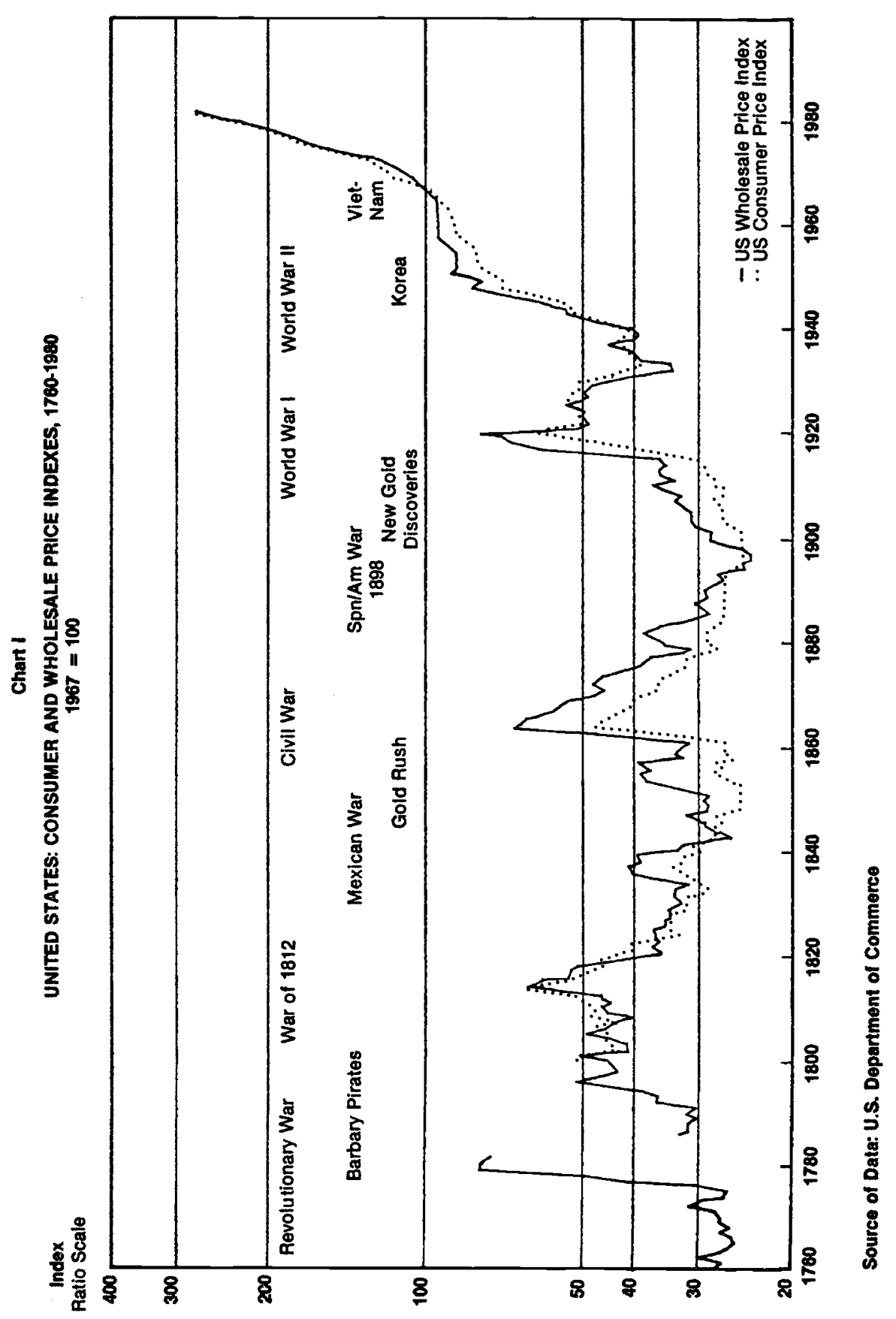


world average. President Nixon introduced price controls in 1971, when inflation was not yet 5 percent.

In the late 1970 s and 1980 s, the U.S. inflation rate rose rapidly. Inflation rates of well over 10 percent were registered by the end of the decade. The U.S. inflation rate did not exceed the world average inflation rate, but the process of accelerating inflation had become deeply ingrained in the American economy. Americans who had hoped that the inflation would prove temporary, or easy to end, or stabilize at relatively low levels, like below 5 percent, or not interfere with real growth and output, were simply proven wrong.

Anti-inflationary programs failed. Changes in analyses or thinking, however, came slower than admissions of failures of policy-making. The U.S. dollar continued weak, but the adoption of a floating rate system with huge monetary interventions obscured the economic significance of changes in exchange markets. The emergence of OPEC surpluses as well as the repeated increases in oil prices again offered convenient simplistic explanations for accelerating inflation and international monetary disorder. Most of the causes for these adverse developments, however, were to be found in the 1950s, 1960s and early 1970s, before the oil price increases.

This brings us to the current conditions and, more particularly, to conditions in money markets. Interest rates have been for many years unpredictable and volatile. We keep on predicting interest rates and keep on being wrong. "Surprise" is the most frequently used word by commentators.

May I make some suggestions as to what to look for in these disturbed times. The first is what I have called the "ski-jump" effect. Interest rates remain high for a considerable period after objective factors are operating which should cause them to decline. Part of the explanation is that the cost of money is influenced by liabilities, like certificates of deposit which do not decline quickly, or by the floating rate instruments which have built-in time lags. More fundamentally, many people who lend (or deposit) remain skeptical of declining inflation rates. They wait and see whether the inflation declines will prove very short-lived before making commitments at newer, lower rates. They expect inflation to become stronger again. The only question is, when. Therefore, they do not hurry to accept lower inflation rates as something that will last and bring lower interest rates. Thus, interest rates can stay high or even rise after the economic situation seemingly calls for a decline, like the earth falling away beneath a ski-jumper who continues to soar because of his or her strong original impetus. The converse is the tendency for interest rates to rise rapidly with early signs of strengthening inflation rates.

A second phenomenon to watch is the "wobble". (See Chart II - next page.) In the world of uncertainty and unpredictability created by persistent inflation and expectations of persistent inflation there are no distinct turning points. We are not able to say where we are in the present business cycle. Like children reciting memorized lessons, we keep on acting as though we can. Instead, economies now wobble. Successive quarters of the supposed cycle since 1976 have not behaved as we thought they should or said they would. We still have the business cycle, but the geometric sine curve which we used as our models of economic behavior leads to oversimplifications and repeated failures and disappointments. 


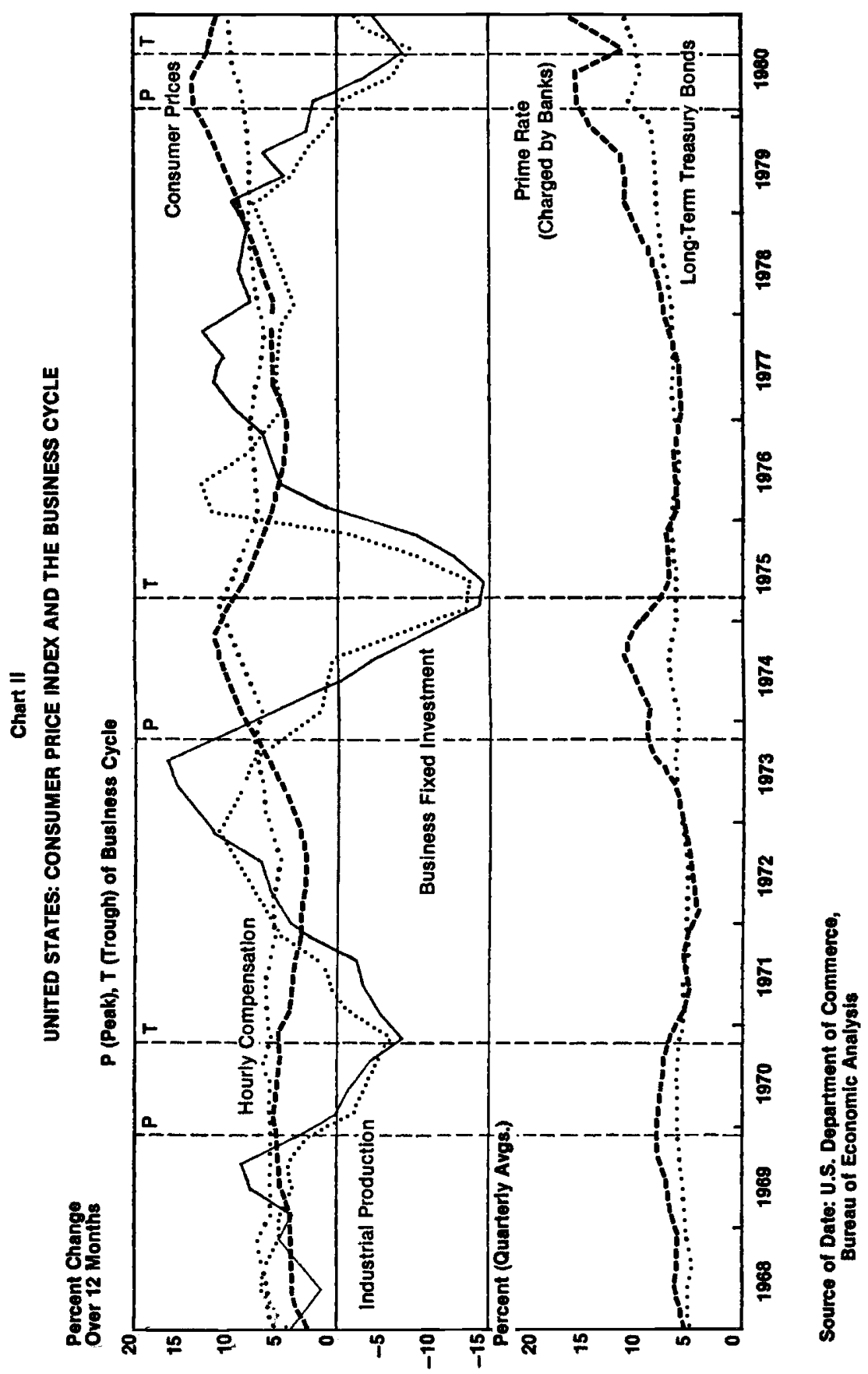


Like froth on turbulent waves, monetary phenomena are even more disturbed. Interest rates rise and fall more within a day than during a whole year in earlier times. In the United States we have seen this volatility of interest rates heightened by so-called " monetarism". Monetarism creates neither high interest rates nor volatility by itself. It heightens both, however, if it is not accompanied by other effective anti-inflationary measures in a comprehensive package of policies.

In our economy, dominated by expectations of persistent inflation, even when we are in a recession, interest rates remain relatively high. If the economy were brought to a zero, or close to zero, growth rate and the outlook were for the continuation of this stagnation for some years, inflation expectations could begin to change and interest rates decline accordingly. This has obviously not happened. As of now, I incline more to the belief of repeated wobbles - with interest rates ending within the year higher than ever.

But what about the relationship between inflation rates and interest rates? This brings me to my third point in watching U.S. inflation/interest rate developments.

Interest rates have followed inflation rates and fluctuated around each other. Indeed, until recently even real short-term rates, though influenced greatly by monetary policy, still did not diverge much from inflation rates. At present, however, the 90 -day Treasury Bill rate may be more than 50 percent higher than the rate of inflation. The prime rates may be more than 100 percent higher than the rate of inflation. What has happened? Can it happen again ?

Some of the explanation is found in the special factors operating in the U.S. money and capital markets, e.g., ceilings on deposits, restrictions on lending, differences in reserve requirements among different kinds of lending institutions, and so forth. More important, I believe, is the impact of persistent inflation and expectations of persistent inflation. Lenders want rates which are high enough to protect them against future inflation as well as current inflation. We should not be surprised if the gap between current short-term rates and inflation rates remain larger than expected.

The behavior of long-term rates also reflects the strengthening of expectations of persistent inflation. The long-term investing public took a relatively optimistic view about long-term inflation rates until the 1970s. Long-term rates tended to be cheap in real terms, particularly on an after-tax basis. In the 1970 s, long-term interest rates rose markedly and remained high, positive and sticky even during business declines. Floating rate loans became popular. Long-term fixed rate loans became increasingly questioned. Time periods shorten during persistent inflation. Even six months, or three months, belong to the unpredictable future when inflation rates may again be much higher. A six-months deposit becomes a "long-term" investment !!!

The Americans, given these experiences, have become most ingenious in devising inflation hedges and tax shelters. How to become a billionaire through exploiting the opportunities created by inflation is the theme of many popular books which increase in number every week. The causes and cures of inflation are set aside to discover how individuals can defend themselves, or even improve themselves, during periods of inflation. That the eventual outcome of persistent inflation is disaster for all, is accepted by most. This does not, however, detract from trying to discover ways and means of living with inflation. Indeed, I find in talking about inflation within the 
United States, people everywhere want to know how people make money in inflationridden countries, like Argentina and Brazil.

What we seem to be seeing in 1981 is an increasingly familiar sight - a lower but still strong rate of inflation, an overall economy which continues to grow in the aggregate while at the same time having serious weaknesses in certain sectors, like housing, construction and automobiles, wide geographical disparities, high and volatile interest rates, poor employment prospects among the young and certain racial groups, continued low savings rates and continued relatively low investment levels. We keep on seeing the phenomenon of weak recessions and weak recoveries.

We may have entered into a period of time when inflationary pressures will be weaker than they have been in recent years. This may well be true for the near future, but I believe that much more has to be changed if we are not to see a revival of stronger inflation before long.

As I see it, the U.S. Administration is not dealing specifically or narrowly with inflation. It is dealing with the profound social and political issues of the role of government in the ways of life of people and the role of government in economic affairs. In so doing the American people and their representatives have been led to review broad social and economic issues like environment, mental health, education, work ethic, savings habits, responsibility of government for education, the position of women in the economy, safety and health, conditions of employment, the distribution of income between public and private use, the relative national priorities in the totality of consumption, including private consumption as well as public, and the federal system with its concerns regarding the relative roles of federal, state and municipal governments, domestic and international migration, treatment of minorities, the geographical pattern of our population spread, the significance of international relations for the American economy, the modernization of our banking system, and so forth. Special mention must be made of the impact of our military and political international relations, directly on defense expenditures, but probably, more importantly, on everything that happens.

This great variety of long-term structural domestic and international issues is still discussed within institutional frameworks like taxation, fiscal expenditures, monetary policy, social security, foreign trade policy, foreign aid, and banking.

At the same time, as these fundamental issues are debated, people also focus on what is happening to interest rates, prices, growth and employment, in the short-term or medium-term.

I believe that we may well see in the months ahead a decline in interest rates, but soon followed by a return to higher levels than ever. I believe that the amplitudes of the downswings and upswings or the timing thereof cannot be predicted. Volatility and the pain of uncertainty will be with us for a long time.

Despite the use of such words as supply side economics, I continue to be concerned as I have been for years that we will in future, as in past decades, take inadequate measures to create the much needed increases in output, efficiency, productivity, and innovation. We are still not creating incentives which are strong enough to move us sufficiently away from inflation hedging or speculation to productive investment. We are not creating, I am afraid, strong incentives to save enough. Stronger 
incentives are needed to persuade people to save more who have experienced inflation for nearly forty years and have found to their sorrow that saving had proven the wrong thing to do. Unless we have much stronger saving incentives, reductions in taxes are likely to strengthen inflationary pressures. We will not have the basis for the increased investment we need.

Many would argue that to change expectations in this fundamental fashion it is necessary to have large scale unemployment and much lower real wages for some years, as well as a decline in real benefits to non-employed people like the young, aged and sick. This philosophy has dominated anti-inflation efforts for many years. Such efforts have thus far not proven successful. It can be argued that such efforts have not been forceful enough to be successful and, in this sense, this approach has not been truly applied. This is surely true in the United States. This is not the approach of the present Administration, nor is it the approach I would favor.

I believe that we can have and indeed need higher levels of growth and reduced unemployment to end inflation. Sufficient austerity can end inflation, but I doubt whether it is practical socially or politically in the United States.

Instead, I believe we should focus our attention on savings. With sufficiently strong incentives, we can induce income earners to refrain from spending their income and save instead. In this way, we can achieve the reduction of consumption which is often sought through increased taxes or decreased real wages or transfer payments. Savings in financial assets can then be channeled through financial institutions into investment. It would take a major revision of our tax laws which are now designed primarily to create revenue for the Federal Government. We do not want to create more revenues for government, but we do not want consumers to spend too much. During this period of history, taxation must again be viewed primarily as a measure to finance government, while voluntary savings are seen as the means of regulating total demand.

As I have tried to say and write in many places over many years, we must close the chronic gap between global supply and global demand not with global inflation, as we do now, nor by trying to repress global demand to the levels of available output, but rather by narrowing the gap through concentrating much more on increasing supply and restraining demand to the new much higher levels of available supply. Increased savings and channeling savings into productive investments are the keys to the solutions.

A great danger is that again monetary policy will be the prime instrument in fighting inflation with little help from other policies. If so, my judgment is that we will fail as we have in the past.

The need remains critical to take more effective measures to bring about a quantum increase in savings and productive investment. Without these very large increases in savings and productive investment we will not get the improvement in efficiency, productivity, innovation and technology which is essential if we are to achieve the end of the dangers and evils of inflation in ways and means acceptable to American society. We have exhausted the option of forced savings by taxation. We need to be much bolder and much more imaginative to create the incentives to move the majority of people from over-consuming and inflation investing to savings and productive investment. 
At this point in time, opinions differ markedly with respect to cyclical conditions in the United States. Many economists see the U.S. economy as having the happier prospect of resumed growth and lower rates of inflation in 1982. Other economists including officials in the Administration, are gloomier about the business outlook. I would stress that because of the previously mentioned wobble effect we really do not know where we are in the business cycle as yet. Indeed, in the last five or six years, we have not had clearly distinguished turning points in the business cycle. Unfortunately, this obscurity lends itself to political controversy. The danger is always present that the short-term horizons, which normally dominate politics, combined with the uncertainty on the outlook create pressures to subordinate the long-run issues of structural change to short-run political expediency.

Thus, the issues of the Great Debate can become mixed with the business cycle management. We need tax reform, we need a review of the role of government, irrespective of where we are in the business cycle. If the Administration's aim is to slow down the economy through monetary restraints, it probably has to continue policies of restraint until these are clearly not any longer necessary. The danger that a "wobble" may be misread prematurely as a change in trend is probably much greater than the danger that policies will continue to be pursued long after they should have been changed. Uncertainty means risk, serious risk.

Inflation, by destabilizing the price mechanism, destabilizes all economic behavior and economic policy-making. Perhaps the greatest danger of all is to fail to recognize that we cannot avoid the risk of serious error until we have ended world inflation. Thus, the Great Debate is inevitably handicapped by the effects of persistent inflation, but were it not for the public opposition to inflation the Great Debate might well not have begun.

The success or failure of the Great Debate will not be whether in the short run prices and interest rates fall or rise. It will be rather whether the needed consensus is found to recreate an efficient, growing American economy and a self-confident American society able, among other things, to end inflation and to end expectations of persistent inflation. It can not be easy, or simple, or quick. 